\title{
The Improvement Ability to Determine the Content and Mandate of Pantun through the Power Point Media of Fifth Grade Student
}

\author{
Deny Setyaningrum \\ SD Negeri Trangkilan \\ denysetyaningrum@gmail.com
}

Article History

accepted 01/11/2020

approved 08/11/2020

published 15/11/2020

\begin{abstract}
The problem that arises in this classroom action research is the low learning outcomes of grade 5 SD Negeri Trangkilan in determining the content and mandate of the pantun. The aim is to determine whether or not the learning outcomes have increased in determining the content and mandate of the rhymes for 5th grade students of SD Negeri Trangkilan through the use of power point media. This classroom action research with the subject of 5th grade students of SD Negeri Trangkilan in the academic year 2020/2021 with a total of 25 students. This classroom action research was conducted in 2 cycles, each cycle consisting of 4 stages, namely, planning, implementing, observing and reflecting. While the research indicator is the completeness of classical learning outcomes. The method of collecting research data is through observation and tests. From the research results indicate an increase in student learning outcomes. Based on the results of data analysis and discussion, namely as follows: that learning completeness from cycle I is $60 \%$ and cycle II is $84 \%$ means that it has increased by $24 \%$.
\end{abstract}

Keywords: ability, content mandate pantun, powerpoint

\begin{abstract}
Abstrak
Permasalahan yang muncul dalam penelitian tindakan kelas ini adalah masih rendahnya hasil belajar siswa kelas 5 SD Negeri Trangkilan dalam materi menentukan isi dan amanat pantun. Tujuannya adalah untuk mengetahui meningkat tidaknya hasil belajar menentukan isi dan amanat pantun pada siswa kelas 5 SD Negeri Trangkilan melalui penggunaan media power point. Penelitian tindakan kelas ini dengan subjek siswa kelas 5 SD Negeri Trangkilan tahun pelajaran 2020/ 2021 dengan jumlah siswa 25 orang. Penelitian tindakan kelas ini dilaksanakan dalam 2 siklus, setiap siklusnya terdiri dari 4 tahap yakni, perencanaan, pelaksanaan, observasi dan refleksi. Sedangkan indikator penelitian adalah ketuntasan hasil belajar klasikal. Cara pengumpulan data penelitian ini yakni melalui observasi dan tes. Dari hasil penelitian menunjukkan adanya peningkatan hasil belajar siswa. Berdasarkan hasil analisis data dan pembahasannya yakni sebagai berikut : bahwa ketuntasan belajar dari siklus I yakni $60 \%$ dan siklus II sebesar $84 \%$ berarti mengalami kenaikan sebesar $24 \%$.
\end{abstract}

Kata kunci: kemampuan, isi amanat pantun, powerpoint

Social, Humanities, and Education Studies (SHEs): Conference Series https://jurnal.uns.ac.id/shes

p-ISSN 2620-9284

e-ISSN 2620-9292 


\section{PENDAHULUAN}

Bahasa adalah satu alat komunikasi, melalui bahasa, manusia dapat saling berkomunikasi, saling berbagi pengalaman, saling belajar dari yang lain, dan meningkatkan kemampuan intelektual. Oleh karena itu belajar bahasa pada hakikatnya adalah belajar komunikasi. Pembelajaran diarahkan untuk meningkatkan kemampuan pembelajaran dalam berkomunikasi, baik lisan maupun tertulis. Hal ini sesuai dengan pendapat yang mengemukakan bahwa pembelajaran Bahasa Indonesia dapat diartikan sebagai sebuah pembelajaran untuk meningkatkan kemampuan siswa dalam komunikasi dengan bahasa baik lisan maupun tulis.

Pembelajaran Bahasa Indonesia adalah salah satu mata pelajaran yang diajarkan di sekolah dasar untuk meningkatkan kemampuan siswa dalam berkomunikasi baik secara lisan maupun secara tertulis. Selanjutnya, pembelajaran Bahasa Indonesia merupakan pembelajaran yang mencakup empat aspek keterampilan yakni mendengarkan (listening), berbicara (speaking), membaca (reading) dan menulis (speaking). Ada dua aspek dalam keterampilan berbahasa yakni keterampilan berbahasa produktif dan keterampilan berbahasa reseptif. Keterampilan berbahasa reseptif adalah terampil atau mampu menerjemahkan kembali kode- kode bahasa menjadi sebuah makna dalam komunikasi baik lisan maupun tertulis. Sedangkan keterampilan berbahasa produktif adalah keterampilan mampu membuat kode- kode kebahasaan yang bermakna dalam komunikasi baik lisan maupun tertulis. Keterampilan mendengarkan dan membaca termasuk ke dalam kemampuan reseptif sedangkan keterampilan berbicara dan menulis termasuk ke dalam keterampilan produktif. Dalam integrasi keempat keterampilan tersebut aspek kebahasaan yang paling sulit adalah menulis karena menulis merupakan tingkat keterampilan berbahasa yang tertinggi.

Berdasarkan observasi penulis, siswa kesulitan dalam menuliskan ide ataupun gagasan untuk dapat membuat suatu pantun karya sendiri. Siswa kadang "macet" dalam mencari kata- kata untuk dapat ditulis menjadi sebuah pantun yang sesuai dengan ciri- ciri pantun yang benar.Dan juga dalam menyimpulkan isi dan amanat pantun, siswa juga mengalami banyak kesulitan. Hal ini kemudian menjadikan materi pantun kurang diminati oleh siswa. Hal ini terlihat dari banyaknya siswa yang kurang aktif dalam pembelajaran yang telah dilaksanakan dan akhirnya berpengaruh pada hasil belajar siswa.

Berdasarkan hasil pengamatan terhadap pembelajaran Bahasa Indonesia selama proses pembelajaran guru belum menggunakan metode belajar yang variatif. Hal ini ditunjukkan dari 25 siswa hanya15 siswa yang aktif pada waktu proses pembelajaran berlangsung tetapi pada saat proses penilaian atau evaluasi pembelajaran hanya 7 peserta didik (28\%) yang tuntas dan belum tuntas KKM sebanyak 18 peserta didik (72\%) dengan nilai Kriteria Ketuntasan Minimal 70.

Secara umum, arti kata kemampuan dalam Kamus Besar Bahasa Indonesia memiliki arti kesanggupan, kecakapan atau kekuatan. Berdasarkan batasan pengertian tersebut kemampuan dapat diartikan sebagai kecakapan sebagai bagian dari kompetensi yang dimiliki oleh seseorang.

Menurut kamus Besar Baahasa Indonesia, kata menentukan memeiliki banyak makna yaitu :(1) membuat menjadi tentu (pasti); menetapkan; memastikan: ;(2) memutuskan; memberi ketentuan: (3) memberi batasan (definisi); (4) memastikan; mengharuskan; mewajibkan. Jadi berdasarkan pengertian tersebut kata "menentukan" dapat diartikan sebagai suatu pemberian batasan yang ditetapkan sebagai sebuah definisi. Dengan kata lain "menentukan" adalah sebuah proses menetapkan atau memberikan sebuah batasan definisi terhadap suatu hal.

Menurut KBBI online pantun adalah bentuk puisi Indonesia (Melayu), yang memiliki ciri- ciri sebagai berikut: (1) Tiap bait (kuplet) biasanya terdiri atas empat baris yang bersajak $a-b-a-b,(2)$ Tiap larik biasanya terdiri atas empat baris (3) Baris pertama 
dan baris kedua biasanya untuk tumpuan (sampiran) saja dan baris ketiga dan keempat merupakan isi;

Berdasarkan uraian di atas kemampuan menentukan isi dan makna pantun adalah suatu kecakapan untuk dapat menetapkan atau memberi arti tentang pesan yang terkandung pada sebuah pantun yang dapat diidentifikasi berdasarkan struktur kebahasaannya pada baris ketiga dan keempat pada bait pantun tersebut.

Menurut Daryanto dalam (Indriyanti: 2017) Media Power Point merupakan sebuah software yang dibuat dan dikembangkan oleh perusahaan microsoft, dan merupakan salah satu program berbasis multimedia. Di dalam komputer program ini biasanya sudah dikelompokkan dalam program microsoft office. Program ini dirancang khusus untuk menyampaikan persentasi dengan berbagai fitur menu yang mampu menjadikannya sebagai media komunikasi yang menarik. Riyana (2008, h. 102) mengatakan "Microsoft Office Power Point memiliki kemampuan untuk menggabungkan berbagai unsur media seperti pengolahan teks, warna, gambar, serta animasi, serta suara".

Adapun tujuan penggunaaan Manfaat media pembelajaran yang dinyatakan oleh : Sudjana dan Rifai dalam (Wulandari: 2016), menyatakan bahwa manfaat media pembelajaran dalam proses belajar siswa yaitu : (1) Dapat menumbuhkan motivasi belajar siswa karena pengajaran akan lebih menarik perhatian mereka, (2) Makna bahan pengajaran akan lebih jelas sehingga dapat dipahami siswa dan memungkinkan terjadinya penguasaan serta pencapaian tujuan pengajaran, (3) Metode mengajar akan lebih bervariasi, tidak semata-mata didasarkan pada komunikasi verbal melalui katakata. Dengan menggunakan media maka metode mengajar akan berbeda disesuaikan dengan materi ajar yang akan diberikan, (4) Siswa lebih banyak melakukan aktivitas selama kegiatan belajar, tidak hanya mendengarkan tetapi juga mengamati, mendemonstrasiskan, melakukan langsung dan memerankan.

Berdasarkan uraian di atas, maka rumusan masalah pada penelitian ini adalah Bagaimana cara meningkatkan kemampuan siswa menentukan isi dan amanat pantun melalui media power point pada peserta didik kelas V SDN Trangkilan tahun pelajaran 2020/ 2021? Tujuan dari penelitian ini adalah mendiskripsikan implementasi media power point untuk meningkatkan kemampuan menentukan isi dan amanat pantun pada peserta didik kelas 5 SD Negeri tahun pelajaran 2020/ 2021.

\section{METODE PENELITIAN}

Jenis penelitian yang digunakan adalah peneltian tindakan kelas (Classroom action research). Penelitian ini dilaksanakan di SD Negeri Trangkilan yang berlokasi di Jalan. Juwana- Wedarijaksa, Kecamatan Wedarijaksa Kabupaten Pati. Adapun subjek penelitian yakni siswa kelas 5 SD Negeri Trangkilan sebanyak 25 siswa, yakni 11 siswa putra dan 14 siswa putri tahun pelajaran 2020/ 2021. Penelitian tindakan kelas ini (PTK) dilaksanakan dalam proses pengkajian yang terdiri atas 4 tahap yakni, perencanaan, pelaksanaan, observasi dan refleksi. Penelitian dilaksanakan dalam 2 siklus yakni siklus I dan siklus II. Waktu penelitian idilaksanakan pada semester ganjil yakni mulai Bulan September sampai dengan November 2020 dan dilakukan secara bertahap. Dalam penelitian ini menggunakan teknik tes dan non tes. Teknik tes yakni menggunakan soal tes evaluasi untuk mengukur kemampuan siswa. Sedangkan untuk teknik non tes yakni menggunakan observasi untuk mengumpulkan data. Adapun untuk alat pengumpul data pada penelitian ini meliputi lembar observasi untuk mengamati guru dan siswa pada saat proses pembelajaran dan lembar tes evaluasi siswa.Data kuantitatif dalam bentuk hasil belajar kognitif dianalisis menggunakan teknik analisis deskriptif dengan menentukan rerata. Data kuantitatif disajikan sebagai prosentase. Data kualitatif disajikan dalam kalimat yang dipisahkan oleh kategori untuk mendapatkan kesimpulan. Data kualitatif ini diperoleh dari mengolah data yang diperoleh dari instrumen pengamatan aktivitas peserta didik atau instrumen pengamatan keterampilan guru. 


\section{HASIL DAN PEMBAHASAN}

Deskripsi kondisi awal kegiatan belajar siswa SD Negeri Trangkilan pada semester ganji tahun pelajaran 2020/ 2021 cenderung pasif yang terefleksi oleh dominasi pembelajaran satu arah oleh guru sehingga hasil pembelajaran kurang bermakna. Adapun hasil belajar pada kondisi awal siswa terkait materi menentukan isi dan amanat yakni sebagai berikut :

\begin{tabular}{llll}
\hline Nilai & Kategori & $\begin{array}{l}\text { PraSiklus } \\
\text { Peserta Didik }\end{array}$ & $\%$ \\
\hline $85-100$ & Sangat Baik & 0 & $0 \%$ \\
$75-84$ & Baik & 2 & $8 \%$ \\
$55-74$ & Cukup & 11 & $44 \%$ \\
$35-54$ & Kurang & 11 & $44 \%$ \\
$0-34$ & Sangat Kurang & 1 & $4 \%$ \\
Jumlah & & 25 & $100 \%$ \\
\hline
\end{tabular}

Dari nilai di atas ketuntasan belajar pada materi yang diajarkan adalah 7 siswa (28\%) sedangkan yang tidak tuntas ada 18 siswa (72\%) dari 25 siswa dengan KKM nilai 70.

\section{Siklus I}

Siklus I dilaksanakan pada tanggal 22 Oktober 2020. Setiap siklus memuat tahap perencanaan, pelaksanaan tindakan, observasi dan refleksi. Pada kegiatan inti, pembelajaran yang dilakukan dengan memberikan tindakan pembelajaran Bahasa Indonesia dengan media power point sederhana non animasi. Pada siklus I diperoleh hasil belajar sebagai berikut:

\begin{tabular}{llll} 
Nilai & Kategori & $\begin{array}{l}\text { Siklus I } \\
\text { Peserta Didik }\end{array}$ & $\%$ \\
\hline $85-100$ & Sangat Baik & 1 & $4 \%$ \\
$75-84$ & Baik & 4 & $16 \%$ \\
$55-74$ & Cukup & 15 & $60 \%$ \\
$35-54$ & Kurang & 5 & $20 \%$ \\
$0-34$ & Sangat Kurang & 0 & $0 \%$ \\
Jumlah & & 25 & $100 \%$ \\
\hline
\end{tabular}

Dari nilai di atas ketuntasan belajar dari materi yang diajarkan yakni 15 peserta didik (60\%) dari 25 siswa. Sedangkan peserta didik yang tidak tuntas sebanyak 10 orang $(40 \%)$. Dari data tersebut terdapat kenaikan ketuntasan peserta didik dari sebesar $32 \%$ dari kondisi awal ke siklus I.

\section{Siklus II}

Pelaksanaan penelitian tindakan kelas berkelanjutan dari siklus pertama ke siklus selanjutnya. Pada siklus I pembelajaran yang sudah dilakukan oleh guru sudah baik namun beberapa siswa masih terlihat mengalami kesulitan dalam memahami materi. Sehingga guru mengambil tindakan dengan menggunakan media power point yang ditambah dengan gambar- gambar dan animasi yang diharapkan dapat meningkatkan antusiasme siswa dalam pembelajaran sehingga dapat meningkatkan hasil belajar siswa materi menentukan isi dan amanat pantun. Siklus ini dilaksanakan pada tanggal 2 November 2020. Berikut adalah hasil belajar pada siklus II 
SHEs: Conference Series 3 (3) (2020) $279-284$

\begin{tabular}{llll}
\hline Nilai & Kategori & $\begin{array}{l}\text { Siklus II } \\
\text { Peserta Didik }\end{array}$ & $\%$ \\
\hline $85-100$ & Sangat Baik & 9 & $36 \%$ \\
$75-84$ & Baik & 9 & $36 \%$ \\
$55-74$ & Cukup & 6 & $24 \%$ \\
$35-54$ & Kurang & 1 & $4 \%$ \\
$0-34$ & Sangat Kurang & 0 & $0 \%$ \\
Jumlah & & 25 & $100 \%$ \\
\hline
\end{tabular}

Dari nilai di atas ketuntasan belajar dari materi yang diajarkan yakni 24 peserta didik $(60 \%)$ dari 25 siswa. Sedangkan peserta didik yang tidak tuntas sebanyak 4 orang $(16 \%)$. Dari data tersebut terdapat kenaikan ketuntasan peserta didik dari sebesar $24 \%$ dari kondisi siklus I ke siklus II.

Berdasarkan hasil pada siklus II menunjukkan guru sudah dapat meningkatkan minat dan antusiasme peserta didik dalam pembelajaran, guru sudah mampu menerapkan penggunaan media power point dengan baik dan dapat mengaktifan siswa dalam pembelajaran. Dilihat dari hasil belajar peserta didik yang sudah memenuhi KKM 70 yakni sebanyak 21 orang atau dalam prosentase sebesar $84 \%$, begitu juga dengan keaktifan sswa dengan rerata $86 \%$. Ha tersebut menunjukkan bahwa tindakan sudah baik.

Berdasarkan uraian di atas tindakan guru dalam menggunakan power point yang disertai gambar- gambar dan animasi serta pembimbingan guru untuk mengaktifkan siswa, maka terjadi peningkatan kemampuan menentukan isi dan amanat pantun di kelas 5 SD Negeri Trangkialn tahun pelajaran 2020/ 2021 pada tingkat ketuntasan belajar yang sudah direncanakan.

Sejalan dengan pendapat dari Hamalik (dalam Indriyani: 2019), yang menyatakan bahwa pemanfaatan media dalam pembelajaran dapat membangkitkan keinginan dan minat baru, meningkatkan motivasi dan rangsangan kegiatan belajar, dan bahkan berpengaruh secara psikologis kepada siswa. Selanjutnya, penggunaan media pembelajaran dapat memberikan fungsi afektif salah satu contohnya adalah pengaruh media visual dapat terlihat dari tingkat keterlibatan emosi dan sikap siswa pada saat menyimak tayangan materi pelajaran yang disertai dengan visualisasi.

Hal tersebut sesuai dengan kerucut pengalaman oleh Edgar Dale (dalam Ulfayana: 2018) yang mengemukakan untuk memahami media dalam proses mendapatkan pengalaman belajar bagi siswa. Edgar Dale menuliskan sebuah kerucut pengalaman bagi siswa yang mana banyak dianut secara luas untuk menentukan alat bantu atau media yang sesuai untuk memperoleh pengalaman belajar secara mudah. Kerucut pengalaman tersebut memberikan gambaran bahwa pengalaman belajar data melalui proses perbuatan atau mengalami sendiri, apa yang dipelajari, proses mengamati dan mendengarkan melalui bahasa. Semakin konkret kita mempelajari bahan pembelajaran, contohnya melalui pengalaman langsung maka semakin banyaklah pengalaman yang diperolehnya. Sebaliknya semakin abstrak kita memperoleh pengalaman, contohnya hanya mengandalkan bahasa verbal, maka akan semakin sedikit pengalaman yang akan diperoleh

Hal tersebut juga sejalan dengan penelitian lain yang mana penggunaan media power point yang dapat meningkatkan minat belajar pserta didik sehingga dapat meningkatkan hasil belajar peserta didik itu sendiri.(Wahidah, Nirmawati, Pujiastuti dan Lukman) 


\section{SIMPULAN}

Berdasarkan hasil penelitian di atas dapat disimpulkan bahwa:

1. Penggunaan media power point pada pembelajaran materi menentukan isi dan amanat pantun dapat meningkatkan keaktifan dan prestasi belajar peserta didik kelas V SD Negeri Trangkilan. Dilihat dari peningkatan hasil belajar siswa pada materi tersebut. Jadi, penggunaan media power point sangat efektif untuk membantu peserta didik lebih memahami konsep materi. Siswa lebih antusias sehingga hasil belajar meningkat.

2. Analisis hasil belajar siswa menunjukkan nilai rata- rata kelas meningkat. Pada saat pra tindakan rata- rata kelas sebesar 56,8 , setelah tindakan siklus I ratarata kelas menjadi 65,6 , dan pada siklus II rata- ratanya sebesar 79,6. Peserta didik yang mengalami ketuntasan juga mengalami peningkatan yakni pada kondisi awal ke siklus I sebesar $32 \%$, dan pada siklus I ke siklus II yakni sebesar 24\%. Sehingga dapat disimpulkan bahwa pengunaan media power point dapat meningkatkan kemampuan peserta didik materi menentukan isi dan amanat pantun pada kelas 5 SD Negeri Trangkilan Tahun pelajaran 2020/ 2021

\section{DAFTAR PUSTAKA}

Indriyani, Lemi(2019).Pemanfaatan Media Pembelajaran dalam Proses Belajar untuk Meningkatkan Kemampuan Berpikir Kognitif Siswa. Prosiding Seminar Nasional Pendidikan, FKIP, Universitas Sultan Ageng Tirtayasa 2 (1), 17-26.

Nirmawati (2018). Pengaruh Penggunaan Media Pembelajaran Power Point terhadap Minat dan Kemampuan Membaca Siswa Pada Mata Pelajaran Bahasa Indonesia Kelas IV. Jurnal Kajian Pendidikan Dasar. 3(1), 429-442.

Ulfayana(2018) . Efektifitas Penggunaan Media Berdasarkan Teori Belajar Edgar Dale Terhadap Peningkatan Hasil belajar Fikihdi MTS Negeri Bulukumba. http://repositori.uin-alauddin.ac.id/12012/1/ULFAYANA.pdf

Lukman (2018). Peningkatan Hasil Belajar Menulis Surat Lamaran Pekerjaan dengan Menggunakan Media Power Point. https://core.ac.uk/download/pdf/228958433.pdf

Wahidah, Miftahul (2017). Penerapan Media Power Point Interaktif untuk Meningkatkan Keterampilan Berbicara Siswa Kelas I SDN Genukwatu IV Ngoro Jombang. http://etheses.uin-malang.ac.id/9742/1/11140050.pdf

Pujiastuti, Arik Umi (2016). Penggunaan Media Power Point denagn Metode Menulis Berantai dalam Pembelajaran Bahasa Indonesia untuk Meningkatkan Keterampilan Menulis Cerita bagi Siswa Kelaa III SD. Jurnal Teladan, Volume 1 No. 1, Mei 2016 file:///C:/Users/hp/Downloads/4-Article\%20Text-16-1-1020181127\%20(1).pdf

Wulandari, Desi (2016).: Pemanfaatan dan Hmabatan Media Power Point Pada Guru SDN Kelas Tinggi Segugus Dewantara Kabupaten banyumas. http://lib.unnes.ac.id/27050/1/1401412015.pdf

Indriyanti, Novi Yulia (2017). Pengembangan Media Pembelajaran Interaktif Berbasis PPT untuk Meningkatkan Hasil belajar IPS Materi : Keragaman Suku Bangsa dan Budaya: Studi Kasus Siswa Kelas VB SDN Karangayu 02 Kota Semarang. http://lib.unnes.ac.id/31035/2/1401413025.pdf

https://kbbi.kemdikbud.go.id/entri/menentukan

diakses tanggal 21 Oktober 2020

https://www.kajianpustaka.com/2019/03/penelitian-tindakan-kelas-ptk.html diakses tanggal 11 Oktober 2020 